Egyptian J. of Nutrition Vol. XXXV No. 1 (2020)

\title{
Ameliorative Effect of Melissaofficinalison Hepatic Toxicity in Rats
}

\section{Hayam A.Elsawy}

Special Food and Nutrition Department, Food Technology Research Institute.Agriculture Research Center, Ministry of Agriculture, Giza,

Egypt.

\section{Abstract}

Due to the industrial revolution in recent days, several air pollutants as carbon tetrachloride $\left(\mathrm{CCL}_{4}\right)$, which has been documented as hepato-degenerative agent; have cumulatively damaged the human health. Therefore, the objective of the current study aimed at investigating the effects of supplementing Carbon tetrachloride $\mathrm{CCL}_{4}$-exposed male Sprague Dawley albino rats with four levels 2.5, 5 and $10 \%$ of Melissa powderedon liver disease. The experiment was carried out on 30 male Albino rats divided into 5 equal groups (each group contain 6 rats); [ $1^{\text {st }}$ group $] f e d$ on basal diet and kept as a control (-).

The other rats were intoxicated by subcutaneous injection of Carbon tetrachloride $\mathrm{CCl}_{4}$ in paraffin oil $(1: 1 \mathrm{v} / \mathrm{v} ; 2 \mathrm{ml} / \mathrm{kg})$ twice a week for two consecutive weeks to induce hepatic chronic damage, then those rats were divided into: a group that control positivecontrol(+) [ $2{ }^{\text {nd }}$ group], a group that fed on basal diet + Melissapowder $2.5 \%$ [ $3^{\text {rd }}$ group]; a group that fed on basal diet +melissapowder $5 \% \quad\left[4^{\text {th }}\right.$ group]; a group that fed on basal diet+Melissa powder $10 \%$ [ $5^{\text {th }}$ group] 


\section{Hayam A. Elsawy}

The results showed that with increasing the amount of melissa powder, the total cholesterol, (TC) triglycerides, (TG) , low density lipoprotein cholesterol,( $\mathrm{LDL}-\mathrm{c})$, very low density lipoprotein cholesterol,( VLDL-C) , Aspartate transaminase, (AST ), alanine transaminase,( $A L T$ ), uric acid, urea nitrogen, creatinine, Iron and TIBC levels decreased significantly and the best result was belonged tothe group of rats that fed on melissa powder $10 \%$.From the obtained results it can be concluded that, supplementation of food bakery with Melissapowder exerts a positive impact on the liver and, kidney functions, lipid profile and other biochemical parameters.

\section{Introduction}

Liver diseases, including hepatitis B virus and hepatitis C virus infections, alcoholic liver disease, nonalcoholic fatty liver disease and associated cirrhosis, liver failure and hepatocellular carcinoma, are major causes of illness and death worldwide. In China, liver diseases affect approximately 300 million (Fu-Sheng et al., 2014). Liver disease causes serious public health problems because of its high prevalence worldwide and poor long-term clinical outcome, including premature deaths from liver decompensation, cirrhosis and hepatocellular carcinoma (Lok., 2004).

Melissa officinalisL. is a plant cultivated in some parts of Iran. The leaves of lemon balm, Melissa officinalisL (Lamiaceae), are used in Iranian folk medicine for their digestive, carminative, antispasmodic, sedative, analgesic, tonic, and diuretic properties, as well as for functional gastrointestinal disorders (Sepide et al., 2017).

Melissaofficinalis L. has a large use in traditional medicine, food industry, and aromatherapy, due to its fresh smell and its medicinal properties including hypoglycemic, hepatoprotective, antimicrobial, antidepressant, hypnotic, and sedative (Miraj et al., 2016). In addition, there are studies that pointed out the cytotoxic effect of lemon balm extract on breast cancer and colon carcinoma (Weidner et al., 2015). 
Egyptian J. of Nutrition Vol. XXXV No. 1 (2020)

Chemical composition of lemon balm contains $15.3 \%$ moisture content and $0.94 \%$ lipid content total Mineral Substances , $7.37 \%$ protein content and $0.94 \%$ lipid content, $\mathrm{Na} 83.34 \mathrm{ppm}, \mathrm{Mn}$ 16.41 ppm, Fe 119 , 4 ppm, Zn 29, 163 ppm, Ni 1.067 ppm, Cu 6.589 ppm (Negrea et al., 2017)

Melissaofficinalis $L$, also known as lemon balm, bee balm, honey balm, (Rasmussen., 2011) is a perennial herb. It is a member of the Lamiaceae (mint) family, and lemon balm (Melissa officinalis $L$ ) belongs to a genus that includes 5 species of perennial herbs native to Europe, Central Asia, and Iran. Although Melissaofficinalis $L$ originated primarily in Southern Europe, it is now naturalized around the world, from North America to New Zealand (Jastrzebska et al., 2013).

The leaf of (Melissa officinalisL,) contains flavonoids (quercitrin, rhamnocitrin, luteolin), polyphenolic compounds (rosmarinic acid, caffeic acid, and protocatechuic acid), monoterpenoid aldehyde, monoterpene glycosides, triterpenes (ursolic and oleanolic acids), sesquiterpenes, tannins, and essential oils (citral) (Sofowora et al., 2013).

It was revealed that essential oils of Melissa officinalis $L$ have good potential for antioxidant activity and can be used in lipidcontaining foods. It is a rich source of antioxidants, in particular from the group of phenolic compounds (Capecka et al., 2005). Its activity is comparable with synthetic antioxidants (BHA and BHT), and antioxidant activity is related to phenolic compounds like citronellal and neral (Meftahizade et al., 2010).

Lemon balm infusion improves plasma levels of catalase, superoxide dismutase, and glutathione peroxidase and a marked reduction in plasma DNA damage, myeloperoxidase, and lipid peroxidation. Due to its iron chelating activity of the extract, its antioxidant potential was increased (Dastmalchi et al., 2008). It was found that flavonoids aglycones were responsible for the free radical scavenging activity and that induced lipid peroxidation in rat cultured hippocampal neurons was significantly inhibited by fractions containing flavonol glycosides, flavonol and biflavone aglycones, or 
chlorogenic acid type phenolics present in the ethanolic extract (Ferreira et al., 2006).

Melissa officinalis $L$ had very high levels of phenolics in 32 plant spices. In another study, it had the highest levels of phenolics and flavonoids (Dias et al., 2012).

From the previous concept the present work was a trial to spot the light on the beneficial effects of (Melissa officinalisL) powder as hepatoprotective agents in rats.

\section{Material}

\section{Materials and methods}

Fresh plant of Melissa officinalis $L$ wereobtainedfromNational Research Center (NRC) in Dokki, Cairo, Egypt. All chemicals used in this experiment were of analytical grade. Kits used for the quantitative determination of the different parameters were purchased from Bio diagnostic Co., Dokki, Giza, Egypt. Wheat flour (72 \% extraction) sucrose, skimmed milk, baking powder, butter, eggs and salt obtained from local market. 30 male Albino rats of Sprague Dawley strain wear obtained from Research Institute of Ophthalmology, Medical Analysis Department, Giza, Egypt.

\section{Methods:}

\section{Preparation of MelissaofficinalisL, Powder:}

Melissa officinalisL, were washed with running tap water and dried by solar energy, (10.5 in hours) temperature $\left(50^{\circ} \mathrm{C}\right)$ relative humidity \% (21) Ibrahim., (1999). The whole quantity was distributed on solar cabinet dryer chamber of solar energy laboratory in the National Research Center was used for dehydration after that the dried plantwas ground into fine powder.

\section{Preparation of cupcake:}

Melissa officinalis $L$ powder was mixed with the wheat flour (72 \% extraction) at 2.5, 5.0, and $10 \%$. Then, $320 \mathrm{~g}$ of the flour mixture was well mixed for 20 min with sucrose $(175 \mathrm{~g})$, skimmed milk $(125 \mathrm{~g})$, baking powder $(10 \mathrm{~g})$, butter $(125 \mathrm{~g})$, eggs $(120 \mathrm{~g})$ and salt (2g). The mixture, with and without Melissa officinalis $L$ illustrated in powder table (1), baked at $275^{\circ} \mathrm{C}$ for $30 \mathrm{~min}$. Then, the cupcakes were allowed to cool and chemically evaluated was done according to the methods outlined in A.A.C. C. (2000). 
Egyptian J. of Nutrition Vol. XXXV No. 1 (2020)

Chemical compositionof (Melissaofficinalis L,) and cupcake:

Melissa officinalis Land cupcakewerechemically analyzed todetermine their moisture, protein, fat, ash, fiber and carbohydrate contentaccording to (A.O.A.C. 2005).

Determination of total flavonoids:

Total flavonoids were estimated using the method of Ordonez et al.(2006).

\section{Determination of total phenolics:}

Total phenol contents in the extracts were determined by the modified Folin-Ciocalteu method of Wolfe et al., (2003).

Determination of antioxidant activity: were determined bythe method of $\boldsymbol{R e}$ et al.(1999).

\section{Sensory evaluation of Cupcake:}

Sensory evaluation of the prepared cupcakes was carried out according to Khalifa et al., (2015). Fresh samples of butter cakes containing, $0.0,2.5,5.0$, and $10 \%$ Melissapowder were sensory evaluated by 20 panelists. All samples were evaluated for color, texture, taste, odor, appearance and overall acceptability using tenpoint hedonic scale, which a score of 10 represented attributes most liked; 5 represented attributes at an unacceptable margin; and 1 represented attributes most disliked.

\section{Biological Assay:}

Thirty male albino rats Sprague Dawley strain weight $180 \pm 10 \mathrm{~g}$ were housed in well-aerated cages under hygienic condition and fed on basal diet (Reeves et al., 1993), for one week for adaptation.

After the period of adaptation on basal diet, the rats were divided into 5equal groups (each group contain 6 rats), the $1^{\text {st }}$ group fed on basal diet as a negative control, the other rats (25 rats) were intoxicated by subcutaneous injection of Carbon tetra chloride $\mathrm{CCl} 4$ in paraffin oil $(1: 1 \mathrm{v} / \mathrm{v} ; 2 \mathrm{ml} / \mathrm{kg})$ twice a week for two consecutive weeks to induce hepatic chronic damage (Jayasekhar et al., 1997). The $2^{\text {nd }}$ group fed on basal diet as apositive control group, The $3^{\text {rd }}, 4^{\text {th }}$ and $5^{\text {th }}$ group fed as the positive control group with 
addition of $2.5,5$ and $10 \%$ melissa powder, respectively.

At the end of the experimental period (28 days), rats were fasted overnight, then anaesthetize \&incised longitudinally and blood samples were collected from the aorta. The blood samples were centrifuged and serum was separated to estimate some biochemical parameters, i.e. Serum cholesterol (Allain T et al., 1974),(TG):

Triglycerides(Fossati, and Prencipl., 1982),(HDL-c): High density lipoprotein cholesterol,(Lopes-Virella et al., 1977),(LDL-c): Low density lipoprotein cholesterol, and Very low density lipoprotein cholesterol,( VLDL-C) ,(Friedewald et al., 1972),, Aspartate transaminase, (AST), and Alanine transaminase, ( ALT ),(Ritman and Frankl., 1957), Urea nitrogen, Creatinine, ,Uric acid.

\section{Histopathological Examination:}

Specimens from liver and spleen were placed in 10\% neutral buffered formalin. The fixed tissues were then trimmed, washed with ice saline and dehydrated in ascending grades of isopropyl alcohol and cleared in xylene. The wax-impregnated tissues were embedded in paraffin blocks using the same grade wax, the paraffin blocks were cut with rotary microtome at $3-5 \mu$ thickness. The sections were floated on a tissue floatation bath at $40^{\circ} \mathrm{C}$ and taken on glass slides. The sections were then melted in an incubator at $60^{\circ} \mathrm{C}$ and after 5 min., they were allowed to cool and stained with Hematoxylin and Eosin according to (Bancroft and Cook, 1998), and examined microscopically at the Faculty of Veterinary Medicine, Cairo University, Egypt.

\section{Statistical analysis:}

Data are presented as means \pm SD and the analysis was conducted using SPSS program, Version 16.0 (2007).

\section{Results and discussion}

Total phenolic, total flavonoid and antioxidant activity of Melissa officinalis L:

Data in table (2) showed the total phenolic $(\mathrm{mg} / \mathrm{g})$, total flavonoid and antioxidant activity (AOA) of Melissa officinalis. Our results agree with who demonstrated that the leaf of Melissa officinalis $L$ contains 13.2 
Egyptian J. of Nutrition Vol. XXXV No. 1 (2020)

mg GAE/100 g dw in 32 plant spices (Koksal et al. 2011). This study showed that antioxidant activity (\%) was higher than that obtained by Kamdem et al. (2013) who found that antioxidant activity was $77.55 \pm 3.7 \%$.

\section{Biological assay:}

Effect of different levels of Melissa powder on FI, BWG, and Relative Organs weight of hepatic rats:

As shown in Table 4, feed intake ofcontrol (+) decreased, then thatof the negative control group. While feeding rats of diet containing 2.5, 5and 10\%MP induced increase in feed intake, as compared to the positive control group.

BWG \% decreed significant in control $(+)$, as compared to the negative control group.

The results in this Table showed non-significant changes in BWG\% in the group fed on diet contain $2.5 \%$ and $5 \% \mathrm{MP}$, as compared to the positive control group.

While treatedrats with $10 \%$ MPinduced significant increase $\mathrm{P}$ $<0.05$, ascompared to the positive control group.Injected rats with CCL4increased liver, kidneys, heart and spleenthan thenegative control rats.However, these increases in vital organs were propagated by MPsupplementation for liver, kidneys, heart and spleen. On the other hand rats given MP show variations in organs weight than control. The body weight is a sensitive indicator that reflects the state of health of experimental animals and the decrease in body weight correlates with defects in body metabolism (Bhatiaand Khera, 2013).

\section{Effect of different levels of Melissa powder on serum lipids fractions of hepatic rats:}

Table (3) illustrated the effect of melissa powder on lipid fractions. The values of serum cholesterol, triglycerides, HDL-C,LDL-C and VLDL-c mg/dl) showed significant increase $(P<0.05)$ for positive control group in compared with negative control group while HDL-c value $(\mathrm{mg} / \mathrm{dl})$ decreased for positive control group significantly,as compared to the control (-) group. Data in this table showed that, total cholesterol $(\mathrm{mg} / \mathrm{dl})$ were increased significantly $(P<0.05)$ for rats 


\section{Hayam A. Elsawy}

(control +). The statistical analysis showed a significant decrease in total cholesterol of all treated groups with Melissapowder when compared with (control +). The lowest decrease in all treated group in cholesterol was recorded in the group fed on diet containing MP $10 \%$. This treatment decreased this parameter by (36\%). Also, the best result of serum triglycerides was observed in the group fed on basal diet containing MP10\% (13.50\%). In this respect Capecka et al., (2005) who found that essential oils of Melissa officinalis $L$ have good potential for antioxidant activity and can be used in lipid-containing foods. It is a rich source of antioxidants, in particular from the group of phenolic compounds.

HDL-c is an effective scavenger of cholesterol molecules from several locations, possibly even from some early plaque formation. Therefore, HDL-c has been considered to be a good lipoprotein and the cholesterol associated with HDL has been referred to be good cholesterol. HDL-c among all groups fed on diet containing MP2.5\%, MP5\%, and MP10\%showed significant increase $<0.05$, compared with (control +).

Low-density lipoprotein cholesterol (LDL-c) of all treated rats with basal diet containing melissa powdered decreased significantly $(\mathrm{P}<0.05)$,compared with control $(+)$. Meanwhile these treatments for rats led to increase LDL-c significantly, compared to (control -).

Very low-density lipoprotein cholesterol (VLDL-c) of rats fed on basal diet decreased significantly $(P<0.05)$, compared to control (+) group. Treating rats with melissa powdered $(2.5 \%, 5 \%$ and $10 \%)$ led to a significant reduction in serum VLDL-c compared with (control + ). The lipid lowering effect of the extract might be due to the action of flavonoids and other phenolic compounds, triterpenoids, alkaloids, steroids and glycosides. Normalized rate of lipogenesis is due to the insulin-like activity of triterpenoids (Sakurai et al., 2002) or activating normoglycemia by the insulin tropic effect of flavonoids (Pinent et al., 2008). Our results agree with who reported that various studies have shown that Melissa officinalis L possesses high amount of antioxidant activity through its chemical compounds including high amount of flavonoids, rosmaric acid, gallic acid, phenolic contents. Many studies confirmed the ant oxidative effects of Melissa officinalis; thus, its effect in preventing and treating oxidative stress-related diseases 
might be reliable (Miraj et al., 2017).In addition, Antioxidant activity of different fractions from Melissa officinalis extract was evaluated, antioxidants are widely used in dietary supplements and have been investigated for the prevention of diseases such as cancer or coronary heart disease (Sepide et al., 2017).

Effect of different levels of melissa powderon serum uric acid, urea nitrogen, and creatininelevels $(\mathrm{mg} / \mathrm{dl})$ of hepatic rats:

Uric acid value,urea nitrogen and creatinine $(\mathrm{mg} / \mathrm{dl})$ of the control positive group showed highly significant increase, as compared to (control -) group the mean values were $(2.99 \pm 0.01$, 44.4. \pm 0.93 and $0.1 .65 \pm 0.06)$ vs. $1.46 \pm 0.05,21.28 \pm 0.99$ and $0.57 \pm 0.02)$ respectively. Results in table (6) indicated that, the mean values of uric acid decreased in the groups fed on diet containing (MP2.5\%, MP5\% and MP10\%), compared with (Control+).

Also, the highest decrease in serum urea nitrogen and creatinine in all treated groups was found in the group fed on diet containing MP10\%. While the highest increase in serum urea nitrogen was observed in MP2.5\% group after control (+).This result agree withSepida et al., (2017)who reported that many studies confirmed the ant oxidative effects of Melissa officinalis; thus, its effect in preventing and treating oxidative stress-related diseases might be reliable. The results of numerous studies on antioxidant or radical scavenging effects may be a basis for detailed in vivo research on anti-inflammatory activities of this plant.First traditional usages of Melissa officinalis and second its antioxidant properties were reviewed in detail. Regarding its traditional usage, antimicrobial activity (antiparasitic, antibacterial, antiviral, etc), antispasmodic, insomnia properties were reported. Many studies confirmed the antioxidative effects of Melissa officinalis; thus, its effect in preventing and treating oxidative stress-related diseases might be reliable. The results of numerous studies on antioxidant or radical scavenging effects may be a basis for detailed in vivo research on antiinflammatory activities of this plant (Sepide et al., 2017).

Effect of different levels of Melissa powder on liver functions (IU/L) of hepatic rats:

Results of AST, ALTALP are presented in Table (7), AST in all treated groups recorded significant decrease $(P<0.05)$, when 
compared with (control + ). On the other hand, the lowest levels of AST enzymes were found in-group of rats fed on diet containing MP10\% (199.31 \pm 0.65$)$.

Also, results obtained from this Table showed a significant increase $(P<0.05)$ in the mean values of ALT and ALP enzymes in the group fed on (control + ), when compared with all treated groups and the best results were observed in the groups that fed on the MP10\% and MP5\% respectively. This result agree with Sofowora et al., (2013) who reported that a radical scavenging and antioxidant potential of polar extracts from Melissa. These activities have arisen from the content of flavonoids, rosmarinic acid, and the benzodioxole. The antioxidant effects of these compounds are up to 10 times stronger than the effects of those of vitamins B and C.

From the obtained results, it can be concluded that, supplementation with high percentage of MP10\% exerts a positive impact on the liver enzymes and other biochemical parameters in hepatic rats. Administration of Melissa officinalis L. extract increased the content of GSH in liver and blood of hyperlipidemic rats (Bolkent et al., 2005).Our result agree with Spide et al., (2017) who reported that the anti-inflammatory activities of Melissa officinalis $L$ leaves were investigated. The essential oil of Melissa officinalis $L$ was shown to have anti-inflammatory activities, supporting the traditional application of this plant in treating various diseases associated with inflammation and pain.

\section{Cupcake composition as affected by melissa powder addition:}

The cupcake composition of unfortified and fortified cupcakes with $2.5,5.0$, and $10 \%$ melissa powder was presented in Table (7). The percentages of moisture, protein, fat, ash, fiber and carbohydrates (control) were 17.73, 7.60, 1.30, 0.71,1.41 and 71.35 $\%$, respectively. Increasing melissa powder addition led to increase the percentage of fiber, ash and fat in the fortified cupcake and decrease the percentage of protein. However, the rest of constituents were slightly changed. Our result agree with (Ivelina et al., 2018) who reported that addition of Melissa increased dietary fiber content and antioxidant activity of bread. The sensory evaluation showed that the addition of $5 \%$ melissa influenced slightly negatively consumers. 
Egyptian J. of Nutrition Vol. XXXV No. 1 (2020)

\section{Sensory evaluation of cupcake as affected by melissa powder} addition:

Table (9) illustrates sensory evaluation scores of fortified cupcake with melissa powder. The mean scores for color, taste, texture, odor, appearance and overall acceptability of unfortified cake (control) were 8.64, 8.7, 8.6, 8.82, 8.71 and 8.63, respectively.

The results of the statistical analysis in this Table showed no significant difference between unfortified cupcake (control sample) and cupcake fortified with $2.5 \%$ melissa. However, comparing with control, fortification of cupcake with $5 \%$, and $10 \%$ melissa resulted in significant decrease $(\mathrm{P}<0.05)$ in all sensory evaluation parameters. This may be due to changes in the chemical composition, fiber content in particular. Competition for water between melissa fiber and other ingredients in the mix as flour and sugars resulting in a significant factor in the contribution of these ingredients to overall cupcake flavor in some formulations (Jasberg, et al., 1989).

\section{Histopathological examination:}

Liver of rat fed on basal diet (control-) showing the normal histological structure of hepatic lobule (Fig.3). Meanwhile, liver of injected rat with CCL4 and fed on basal diet (control+) showing portal infiltration with leucocytes (Fig.4 and 5) and Liver of injected rat with $\mathrm{CCL}_{4}$ and fed on basal diet (control + ) showing vacuolations of hepatocytes and focal hepatic necrosis associated with leukocyte cells infiltration.

Moreover, liver of rat suffering from chronic liver diseases and treated daily with Melissa powder 2.5\% (MP 2.5\%) showing vacuolations of centro lobular hepatocytes (Fig. 6). Liver of rat suffering from chronic liver diseases and treated daily with MP 5\% showing slight congestion of central vein (Fig.7). Liver of rat suffering from chronic liver diseases and treated daily with MP $10 \%$ showing no histopathological changes (Fig. 8). 
Hayam A. Elsawy

Table (1): Contents of cupcake with and without (Melissa officinalis L.) powder $(\mathrm{g} / 100 \mathrm{~g})$.

\begin{tabular}{|c|c|c|c|c|c|c|c|c|c|}
\hline \multicolumn{2}{|c|}{ Types of cupcakes } & MP & Flour & Sucrose & $\begin{array}{c}\text { Skimmed } \\
\text { milk }\end{array}$ & $\begin{array}{l}\text { Baking } \\
\text { powder }\end{array}$ & Butter & Eggs & Salt \\
\hline \multirow{4}{*}{$\begin{array}{c}\text { control } \\
\text { Cupcake } \\
\text { fortified with }\end{array}$} & - & 0.0 & 320 & 175 & 125 & 10 & 125 & 120 & 2 \\
\hline & MP $2.5 \%$ & 8 & 312 & 175 & 125 & 10 & 125 & 120 & 2 \\
\hline & MP $5 \%$ & 16 & 304 & 175 & 125 & 10 & 125 & 120 & 2 \\
\hline & MP $10 \%$ & 24 & 296 & 175 & 125 & 10 & 125 & 120 & 2 \\
\hline
\end{tabular}

MP: Mellissa officinalis $L$ powder.

Table (2): Total phenolic compounds total flavonoid and Antioxidant Activity ofMelissa officinalis L.

\begin{tabular}{l|l}
\hline Component & Value \\
\hline Total phenolic $(\mathrm{mg} / \mathrm{g})$ & $13.57 \pm 0.24$ \\
\hline Total flavonoid $(\mathrm{mg} / \mathrm{g})$ & $24.06 \pm 0.96$ \\
\hline Antioxidant Activity (AOA \%) & $86.96 \pm 0.28$ \\
\hline Mean \pm SD &
\end{tabular}

Table (3): Effect of some levels of melissa powder on FI, BWG\% and relative organs weight of hepatic rats.

\begin{tabular}{c|c|c|c|c|c|c}
\hline \multirow{2}{*}{$\begin{array}{c}\text { Parameters } \\
\text { Groups }\end{array}$} & \multirow{2}{*}{ FI (gm/day) } & \multirow{2}{*}{ BWG\% } & \multicolumn{4}{|c}{ Organ weight/body weight (\%) } \\
\cline { 4 - 7 } Control (-) & \multirow{2}{*}{16.92} & $\begin{array}{c}47.46 \\
\pm 1.06^{\mathrm{A}}\end{array}$ & $\begin{array}{c}3.08 \\
\pm 0.01^{\mathrm{D}}\end{array}$ & $\begin{array}{c}0.63 \\
\pm 0.011^{\mathrm{B}}\end{array}$ & $\begin{array}{c}0.32 \\
\pm 0.01^{\mathrm{CD}}\end{array}$ & $\begin{array}{c}0.22 \\
\pm 0.02^{\mathrm{E}}\end{array}$ \\
\hline \multirow{2}{*}{ Control (+) } & \multirow{2}{*}{13.58} & $\begin{array}{c}-34.26 \\
\pm 1.94^{\mathrm{C}}\end{array}$ & $\begin{array}{c}3.93 \\
\pm 0.04^{\mathrm{A}}\end{array}$ & $\begin{array}{c}0.68 \\
\pm 0.00^{\mathrm{A}}\end{array}$ & $\begin{array}{c}0.38 \\
\pm 0.01^{\mathrm{A}}\end{array}$ & $\begin{array}{c}0.45 \\
\pm 0.0 .01^{\mathrm{A}}\end{array}$ \\
\hline \multirow{2}{*}{ MP 2.5\% } & \multirow{2}{*}{14.12} & $\begin{array}{c}-33.86 \\
\pm 0.01^{\mathrm{C}}\end{array}$ & $\begin{array}{c}3.51 \\
\pm 0.00^{\mathrm{B}}\end{array}$ & $\begin{array}{c}0.65 \\
\pm 0.01^{\mathrm{B}}\end{array}$ & $\begin{array}{c}0.36 \\
\pm 0.02^{\mathrm{AB}}\end{array}$ & $\begin{array}{c}0.41 \\
\pm 0.00^{\mathrm{B}}\end{array}$ \\
\hline \multirow{2}{*}{ MP 5\% } & \multirow{2}{*}{14.31} & $\begin{array}{c}-33.10 \\
\pm 0.81^{\mathrm{C}}\end{array}$ & $\begin{array}{c}3.41 \\
\pm 0.03^{\mathrm{C}}\end{array}$ & $\begin{array}{c}0.64 \\
\pm 0.01^{\mathrm{B}}\end{array}$ & $\begin{array}{c}0.35 \\
\pm 0.01^{\mathrm{BC}}\end{array}$ & $\begin{array}{c}0.33 \\
\pm 0.00^{\mathrm{C}}\end{array}$ \\
\hline \multirow{2}{*}{ MP 10\% } & 14.75 & $\begin{array}{c}-22.38 \\
\pm 0.03^{\mathrm{B}}\end{array}$ & $\begin{array}{c}3.13 \\
\pm 0.02^{\mathrm{D}}\end{array}$ & $\begin{array}{c}0.62 \\
\pm 0.02^{\mathrm{B}}\end{array}$ & $\begin{array}{c}0.31 \\
\pm 0.015^{\mathrm{D}}\end{array}$ & $\begin{array}{c}0.28 \\
\pm 0.01^{\mathrm{D}}\end{array}$ \\
\hline LSD & - & 1.925 & 0.051 & 0.027 & 0.028 & 0.018 \\
\hline COnnyyyy
\end{tabular}

Control (-): Control Negative.

Control (+): Control Positive.

MP2.5\%: Melissa Powder $2.5 \%$ MP5 \%: Melissa Powder 5\% MP10 \%: Melissa

Powder $10 \%$

Values are expressed as mean \pm SD.

Significance at $p<0.05$.

Values, which don't share the same letter in each column, are significantly different. 
Egyptian J. of Nutrition Vol. XXXV No. 1 (2020)

Table (4): Effect of different levels of melissa powder on serum lipids fractions of hepatic rats.

\begin{tabular}{l|c|c|c}
\hline Groups & Uric acid mg/dl & Urea nitrogen mg/dl & Creatinine mg/dl \\
\hline Control (-) & $1.46 \pm 0.05^{\mathrm{C}}$ & $21.28 \pm 0.99^{\mathrm{D}}$ & $0.57 \pm 0.02^{\mathrm{D}}$ \\
\hline Control (+) & $2.99 \pm 0.01^{\mathrm{A}}$ & $44.40 \pm 0.93^{\mathrm{A}}$ & $1.65 \pm 0.06^{\mathrm{A}}$ \\
\hline MP 2.5\% & $2.63 \pm 0.00^{\mathrm{B}}$ & $38.58 \pm 0.67^{\mathrm{B}}$ & $1.35 \pm 0.02^{\mathrm{B}}$ \\
\hline MP 5\% & $2.59 \pm 0.14^{\mathrm{B}}$ & $36.94 \pm 0.23^{\mathrm{B}}$ & $1.32 \pm 0.02^{\mathrm{B}}$ \\
\hline MP 10\% & $2.57 \pm 0.01^{\mathrm{B}}$ & $32.12 \pm 1.89^{\mathrm{C}}$ & $1.16 \pm 0.05^{\mathrm{C}}$ \\
\hline LSD & 0.128 & 1.991 & 0.077 \\
\hline
\end{tabular}

Control (-): Control Negative.

Control (+): Control Positive.

MP2.5\%: Melissa Powder $2.5 \%$ MP5 \%: Melissa Powder 5\% MP10 \%: Melissa Powder $10 \%$

TC: Cholesterol TG: Triglycerides HDL: High-density lipoprotein cholesterol

LDL: Low-density lipoprotein cholesterol VLDL: Very low-density lipoprotein cholesterol,

Values are expressed as mean $\pm S D$. Significance at $p<0.05$.

Values, which don't share the same letter in each column, are significantly different 
Hayam A. Elsawy

Table (5): Effect of different levels of melissa powder on serum uric acid and creatinine urea nitrogen levels $(\mathrm{mg} / \mathrm{dl})$ of hepatic rats.

\begin{tabular}{l|c|c|c|c|c}
\hline \multirow{2}{*}{ Garameters } & \multicolumn{5}{|c}{ Lipid Fraction $(\mathrm{mg} / \mathrm{dl})^{2}$} \\
\cline { 2 - 6 } & TC & TG & HDL & LDL & VLDL \\
\hline Control (-) & $89.04 \pm 0.82^{\mathrm{C}}$ & $46.54 \pm 0.53^{\mathrm{D}}$ & $55.50 \pm 1.36^{\mathrm{A}}$ & $23.08 \pm 0.79^{\mathrm{D}}$ & $9.52 \pm 0.61^{\mathrm{C}}$ \\
\hline Control (+) & $226.51 \pm 1.35^{\mathrm{A}}$ & $103.13 \pm 1.90^{\mathrm{A}}$ & $40.56 \pm 1.21^{\mathrm{C}}$ & $167.73 \pm 2.21^{\mathrm{A}}$ & $22.34 \pm 0.49^{\mathrm{A}}$ \\
\hline MP 2.5\% & $211.21 \pm 1.10^{\mathrm{AB}}$ & $95.04 \pm 1.29^{\mathrm{B}}$ & $45.79 \pm 0.83^{\mathrm{B}}$ & $146.33 \pm 0.79^{\mathrm{B}}$ & $18.40 \pm 0.49^{\mathrm{B}}$ \\
\hline MP 5\% & $194.84 \pm 0.52^{\mathrm{AB}}$ & $86.40 \pm 2.92^{\mathrm{B}}$ & $46.35 \pm 0.14^{\mathrm{B}}$ & $136.44 \pm 2.50^{\mathrm{C}}$ & $17.85 \pm 0.03^{\mathrm{B}}$ \\
\hline MP 10\% & $140.05 \pm 0.61^{\mathrm{BC}}$ & $86.11 \pm 1.19^{\mathrm{C}}$ & $46.75 \pm 1.33^{\mathrm{B}}$ & $131.71 \pm 0.75^{\mathrm{C}}$ & $16.64 \pm 0.59^{\mathrm{B}}$ \\
\hline L.S.D & 85.12 & 3.21 & 3.21 & 1.97 & 2.93
\end{tabular}

Control (-): Control Negative.

Control (+): Control Positive.

MP2.5\%: Melissa Powder $2.5 \%$ MP5 \%: Melissa Powder 5\% MP10 \%: Melissa Powder $10 \%$

Values are expressed as mean \pm SD.

Significance at $p<0.05$. Values, which do not share the same letter in each column, are significantly different.

Table (6) :Effect of different levels of Melissa powder on liver functions $(\mathrm{IU} / \mathrm{L})$ of hepatic rats.

\begin{tabular}{|c|c|c|c|}
\hline $\begin{array}{ll}\text { Groups } & \text { Parameters } \\
\end{array}$ & AST & ALT & ALP \\
\hline Control (-) & $58.07 \pm 0.11^{\mathrm{E}}$ & $27.38 \pm 0.33^{C}$ & $87.29 \pm 1.00^{\mathrm{D}}$ \\
\hline Control (+) & $238.75 \pm 1.50^{\mathrm{A}}$ & $147.67 \pm 0.51^{\mathrm{A}}$ & $308.62 \pm 2.19^{A}$ \\
\hline MP $2.5 \%$ & $216.66 \pm 3.71^{B}$ & $135.73 \pm 1.83^{\mathrm{AB}}$ & $293.09 \pm 3.51^{\mathrm{B}}$ \\
\hline MP 5\% & $205.2 \pm 2.45^{\mathrm{C}}$ & $128.51 \pm 0.64^{\mathrm{AB}}$ & $284.87 \pm 4.33^{\mathrm{C}}$ \\
\hline MP $10 \%$ & $199.31 \pm 0.65^{D}$ & $97.41 \pm 0.96^{\mathrm{B}}$ & $284.69 \pm 5.62^{\mathrm{C}}$ \\
\hline L.S.D & 3.85 & 49.02 & 6.73 \\
\hline
\end{tabular}

Control (-): Control Negative.

Control (+): Control Positive.

MP2.5\%: Melissa Powder 2.5 \% MP5 \%: Melissa Powder 5\% MP10 \%: Melissa

Powder $10 \%$

Values are expressed as mean \pm SD. Significance at $p<0.05$.

Values, which don't share the same letter in each column, are significantly different.

AST: Aspartate transaminase ALT: Alanine transaminase ALP: Alkaline Phosphatase 
Egyptian J. of Nutrition Vol. XXXV No. 1 (2020)

Table (7): Proximate cupcakes composition as affected by melissa powder addition(wet weight bases).

\begin{tabular}{|c|c|c|c|c|c|c|}
\hline Samples $\quad$ Parameters & Moisture & Protein & Fat & Ash & Fiber & Carbohy-drates \\
\hline Control* $^{*}$ & 17.73 & 7.60 & 1.40 & 0.71 & 1.31 & 71.25 \\
\hline MP $2.5 \%$ & 13.15 & 7.30 & 1.10 & 0.72 & 0.52 & 77.21 \\
\hline MP 5\% & 14.31 & 6.60 & 1.30 & 0.97 & 0.81 & 77.41 \\
\hline MP $10 \%$ & 16.16 & 6.31 & 1.45 & 0.99 & 1.02 & 74.07 \\
\hline
\end{tabular}

Table (8): Sensory evaluation of cupcakes as affected by melissa powder addition.

\begin{tabular}{l|c|c|c|c|c|c}
\hline $\begin{array}{c}\text { Premaster } \\
\text { Samples }\end{array}$ & Color & Taste & Texture & Odor & Appearance & $\begin{array}{c}\text { Overall } \\
\text { acceptability }\end{array}$ \\
\hline Control $^{*}$ & $\begin{array}{c}8.64 \\
\pm 0.25 \mathrm{a}\end{array}$ & $\begin{array}{c}8.7 \\
\pm 0.15 \mathrm{a}\end{array}$ & $\begin{array}{c}8.6 \\
\pm 0.12 \mathrm{a}\end{array}$ & $\begin{array}{c}8.82 \\
\pm 0.09 \mathrm{a}\end{array}$ & $\begin{array}{c}8.71 \\
\pm 5.86 \mathrm{a}\end{array}$ & $\begin{array}{c}8.63 \\
\pm 0.29 \mathrm{a}\end{array}$ \\
\hline MP2.5\% & 8.40 & 8.4 & 8.73 & 8.32 & 8.59 & 8.62 \\
& $\pm 9.69 \mathrm{a}$ & $\pm 0.17 \mathrm{a}$ & $\pm 0.35 \mathrm{a}$ & $\pm 0.36 \mathrm{a}$ & $\pm 0.15 \mathrm{a}$ & $\pm 0.18 \mathrm{a}$ \\
\hline MP 5\% & 5.8 & 5.8 & 5.87 & 5.46 & 5.53 & 7.93 \\
& $\pm 1.34 \mathrm{~b}$ & $\pm 1.13 \mathrm{~b}$ & $\pm 1.54 \mathrm{~b}$ & $\pm 1.48 \mathrm{~b}$ & $\pm 1.17 \mathrm{~b}$ & $\pm 0.12 \mathrm{ab}$ \\
\hline \multirow{2}{*}{ MP 10\% } & 5.53 & 5.6 & 5.60 & 5.30 & 5.53 & 7.03 \\
& $\pm 0.65 \mathrm{~b}$ & $\pm 0.46 \mathrm{~b}$ & $\pm 0.10 \mathrm{~b}$ & $\pm 0.97 \mathrm{~b}$ & $\pm 0.33 \mathrm{~b}$ & $\pm 0.76 \mathrm{c}$ \\
\hline
\end{tabular}

Control: wheat flour (72\% extraction), The average of total score was converted to a descriptive category as follows: Judging scale: very good (9-8), Good (6-7), Fair (45), Poor (2-3) and Very Poor (1). All results are expressed as mean \pm SD Means followed by different superscripts within columns are significantly different $(\mathrm{P}<0.05)$. 
Hayam A. Elsawy 
Egyptian J. of Nutrition Vol. XXXV No. 1 (2020) 
Hayam A. Elsawy 
Egyptian J. of Nutrition Vol. XXXV No. 1 (2020) 


\section{REFERENCES}

A.A.C.C. (2000):

Approved methods of the American Association of Cereal Chemists. St. Paul. Minnesota: The American Association of Cereal Chemists Inc.

Allain, C. Z.; Poon-L. S. and Chan, C. S. (1974):

Enzymatic determination of total serum cholesterol. Clin. Chem.; 20:470-475.

A.O.A.C. (2005):

Official methods of analysis of the association of official analytical chemistry, $15^{\text {th }}$ ed. Washington, D.C.

Bancroft, J. D.; Cook, H. C. (1998):

Manual of histotechnologist techniques. Edited by: Churchi Livingstone., New York: 243.

Bhatia, A. and Khera, N. (2013):

Hypoglycemic activity of orally administered Woodforde fruticose flower extract in alloxan-induced diabetic mice. Int $\mathrm{J}$ Life Sci Biolechnol Pharm Res., 2:2250-3137. 
Egyptian J. of Nutrition Vol. XXXV No. 1 (2020)

Bolkent,S., Yanardag, R., Karabulut-Bulan, O., \&Yesilyaprak, B. (2005).

Protective role of Melissa officinalis L. extract on liver of hyperlipidemic rats: a morphological and biochemical study. Journal of ethnopharmacology, 99 (3), 391-398.

Capecka E, Mareczek A, Leja M. (2005):

Antioxidant activity of fresh and dry herbs of some Lamiaceae species. Food Chem.; 93:223-226.

Dastmalchi K, Dorman HD, Oinonen PP, Darwis Y, Laakso I, Hitunen R. (2008):

Chemical composition and in vitro ant oxidative activity of a lemon balm (Melissa officinalis L.) extract. LWT Food Sci Technol. 41:391-400

Dias MI, Barros L, Sousa MJ, Ferreira IC. (2012):

Systematic comparison of nutraceuticals and antioxidant potential of cultivated, in vitro cultured and commercial Melissa officinalis samples. Food ChemToxicol.50:1866-1873.

Ferreira A, Proenca C, Serralheiro M, Araujo M. (2006):

The in vitro screening for acetylcholinesterase inhibition and antioxidant activity of medicinal plants from Portugal. $J$ Ethnopharmacol.108:31-37 


\section{Hayam A. Elsawy}

Fossati, P. and Prencipl, L. (1982):

Enzymatic colorimetric determination of serum triglycerides. Clin. Chem., 28:2077.

Friedewald, W. T.; Leve, R. I. and Fredrichson, D. S. (1972):

Estimation of concentration of low-density lipoproteins separated by three different. Clin. Chem.; 18:499-502.

Fu-Sheng W., Jian-Gao F., Zheng Z., Bin G., and Hong-Yang W.,(2014):

The Global Burden of Liver Disease: The Major Impact of China. Hepatology. 60(6): 2099-2108.

Ibrahim S. S. (1999):

Comparative evaluation of two different forms of dietary fiber on atherosclerosis in rats. MSc. Thesis Home Economics, Helwan Univ. Nutrition and Food Science Dept., P. 16

Ivelina V. ; Rositsa D; Rosen C ; Desislava T; Zapryana D; Tzvetelin D ; Petko D and Anton S (2018):

Effect of lavender (Lavandula angustifolia) and melissa (Melissa Officinalis) waste on quality and shelf life of bread. Food Chemistry 253 (2018) 13-21 
Egyptian J. of Nutrition Vol. XXXV No. 1 (2020)

Jasberg, B.K., Gould, JM, and Warner, K. (1989):

Higher-fiber, no caloric flour substitute for baked foods, alkaline peroxide-treated lignocellulose in chocolate cake. Cereal Chem. 66: 209-213

Jastrzębska-Stojko Z, Stojko R, Rzepecka-Stojko A, Kabała-Dzik A, Stojko J. (2013):

Biological activity of propolis-honey balm in the treatment of experimentally-evoked burn wounds. Molecules.;18:1439714413.

Jayasekhar P., Mohanan, P.V., Rathinam, K. (1997):

Hepatoprotective activity of ethyl acetate extract of Acacia catechu. Indian Journal of Pharmacology, 29: 426-428.

Kamdem,J.P. A. Adeniran, A.A. Boligon, C.V. Klimaczewski, O.. Elekofehinti, W. Hassan, M. Ibrahim, E.P. Waczuk, D.F. Me inerz, M.L. Athayde (2013):

Antioxidant activity, genotoxicity and cytotoxicity evaluation of lemon balm (Melissa officinalis L.) ethanolic extract: its potential role in neuroprotectionlnd. Crop. Prod., 51, pp. 2634

Khalifa, I., Hassan B., Hamdy A. and Soliman A. S., (2015):

Physico-Chemical, Organolyptical and Microbiological Characteristics of Substituted Cupcake by Potato Processing Residues, Food and Nutrition Sciences, 2015, 6, 83-100. 


\section{Hayam A. Elsawy}

Koksal, E., Bursal, E., Dikici, E., Tozoglu, F., \& Gulcin, I. (2011). Antioxidant activity of Melissa officinalis leaves. Journal of Medicinal Plants Research, 5(2), 217-222.

Lok *AS. (2004):

Prevention of hepatitis B virus-related hepatocellular carcinoma. Gastroenterology. 2004;127: S303-S309.

Lopes-virella, M. F.; Stone, S.; Ellis, S. and Collwell, J. (1977):

Cholesterol determination in high density lipoproteins separated by three different methods. Clin. Chem.; 23 (5) 882.

Meftahizade H, Sargsyan E, Moradkhani H. (2010):

Investigation of antioxidant capacity of Melissa officinalis L. essential oils. J Med Plant Res.; 4:1391-1395.

Miraj S., Azizi N., Kiani S. (2016):

A review of chemical components and pharmacological effects of Melissa officinalis L. 2016;8 (6):229-237.

Miraj S, Rafieian-Kopaeil, Kiani S (2017):

Melissa officinalis L: A Review Study With an Antioxidant Prospective. J. Evid Based Complementary Altern Med. 2017 Jul; 22 (3):385-394. 
Egyptian J. of Nutrition Vol. XXXV No. 1 (2020)

Negrea, M; Alexa, E; Sumalan, R.; obistioiu D.; cocan, I.; Poiana, A. and Tulcan, C.;(2017):

Chemical constituents, antioxidant and antifungal Potential of Melissa officials formulations. Journal of international Scientific Publications. Ecology \& Safety. ISSN 1314-7234, Vol. 11, 2017

OrdoÒez A.A.L., Gomez J.G., Vattuone M.A., Isla M.I. (2006):

Food Chem. 97, 452.

Penfield, M. and Campbell, A., M. (1990):

Experimental food science, 3rd ed. (ed). Academic Press, Inc. London, P.33-34.

Pinent, M., Castell, A., Baiges, I., Montagut, G., Arola, L. and Ardevol, A. (2008):

Bioactivity of flavonoids on insulin- secreting cells. Compr Rev Food Sci Food safe., 7(4):299-308.

\section{Rasmussen P.(2011);}

Lemon balm-Melissa officinalis, also known as lemon balm, bee balm, garden balm, Melissa, melissengeist. J Prim Health Care. 2011;3: 165-166

Re R., Pellegrini N., Proteggente A., Pannala A., Yang M., RiceEvans C. (1999):

Free Radic. Biol. Med. 26, 1231 


\section{Hayam A. Elsawy}

Reeves, P.G., Nielsen, F.H. and Fahey, G.C. (1993):

AIN-93 purified diets for laboratory rodents: Final report of the American Institute of Nutrition adhoc writing committee on the reformulation of the AIN-76A rodent diet. J. Nutr.,123 (11):1939-1951.

Reitman, S. and Frankel, S. (1957):

A colorimetric methods for the determination of serum glutamic oxaloacetic and glutamic pyruvic transaminase. Am. J. Clin. Path Crops and Products, 51, 26-34.

Sakurai, T., Nishimura, T., Otake ,N., Xinsheng, Y., Abe, K., Zeida, M., Nagasawa, H. and Sakuda, S. (2002):

Assamicin I and II, novel triterpenoid saponins with insulinlike activity fromAesculus assamicaGriff. Bioorg Med Chem Lett., 12 (5):807-810.

Sepide M., Rafieian-K, and Sara, K. (2017):

Melissa officinalis L: A Review Study With an Antioxidant Prospective. J. Evid. Based Complementary Altern Med. 2017 Jul; 22(3): 385-394.

Sofowora A, Ogunbodede E, Onayade A. (2013):

The role and place of medicinal plants in the strategies for disease prevention. Afr $\mathrm{J}$ Tradit Complement Altern Med. 2013; 10:210-229. 
Egyptian J. of Nutrition Vol. XXXV No. 1 (2020)

SPSS. (2007):

Statistical Package for Social Science, SPSS Inc., Chicago, IL, USA Copyright@ for Windows, version 16.0 (2007).

Weidner C., Rousseau M., Plauth A., (2015):

Melissa officinalis extract induces apoptosis and inhibits proliferation in colon cancer cells through formation of reactive oxygen species. 2015;22(2):262-270.

Wolfe K., Wu X., Liu R.H. (2003):

Antioxidant activity of apple peels. J. Agric. Food Chem. 51, 609

Wojdyło A, Oszmian'ski J, Czemerys R. (2007):

Antioxidant activity and phenolic compounds in 32 selected herbs. Food Chem.;105: 940-949.

Wikipedia en.wikipedia.org, Melissa (plant) . 
التأثير المحسن لعشبة المليسيا على التسمم الكبدي في الجرذان

\section{هيام عبد العزيز الصاوى}

\section{مركز البحوث الزراعية ـمعهد بحوث تكنولوجياالأغذية ـ قسم الأغذية الخاصة}

\section{الملخص العربي}

نظر اللثورة الصناعية في العصر الحديث انتشرت الملوثات الجوية مسببة أضراراً جمة

على صحة الإنسان. ومن تللك الملوثات مركب رابع كلوريد الكربون الضار بصحة وسلامة

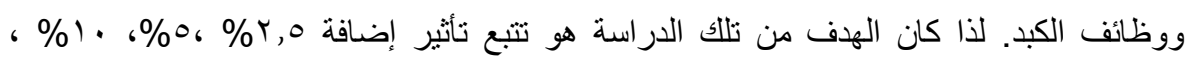

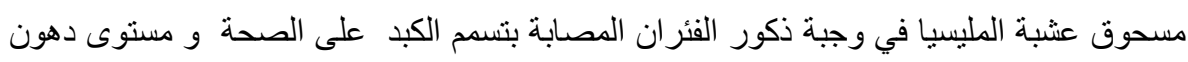

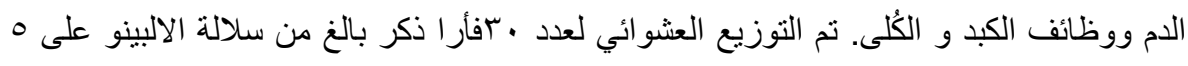

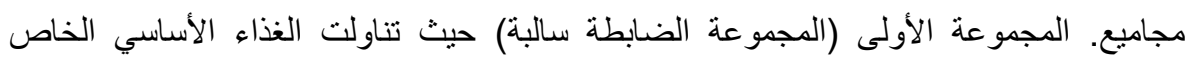

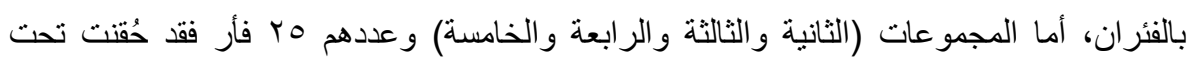

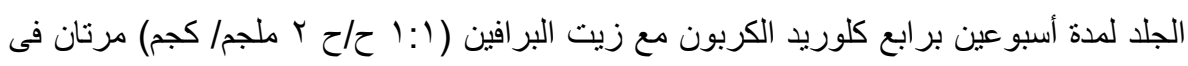
الاسبوع، لمدة اسبو عين متتاليين لإحداث خلل كبدي واعتبرت المجموعة الثانية(كونترول موجب) حيث تناولت الغذاء الأساسي فقط، أما المجموعة الثالثة والرابعة والخامسة فقد تناولت الغذاء

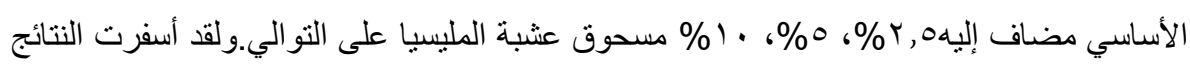
عن حدوث نقص معنوي في صورة الكوليسترول الكلى والجليسريدات الثثلاثية وكذلك إنزيمات

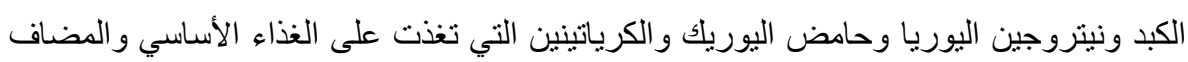
إلية نسب عالية من مسحوق عشبة المليسيا. وكانت أفضل النتائج للمجموعة التى تغذت على على لئى مسحوق عشبة المليسيا · (\%). وتوصى الدراسة بتدعيم الوجبات والمنتجات الغذائية بمسحوق عثبة المليسيا وذلك لما أظهره من نتائج ايجابية في تحسين وظائف الكبد والكلى وكذلك صورة الكية الدهون في الدم وبعض القياسات البيو كيميائية الأخرى. 